\title{
Growth and volatile compounds of Martianthus leucocephalus exposed to heavy metal stress
}

\author{
Crescimento e teor de compostos voláteis de Martianthus leucocephalus \\ submetida ao estresse por metais
}

\author{
Daniel da Silva de Jesus ${ }^{\mathrm{I}}{ }^{*}$ Bianca Oliveira de Azevedo ${ }^{\mathrm{I}}$ Milena Santos Pinelli ${ }^{\mathrm{II}}$ \\ Maria das Graças Andrade Korn ${ }^{\text {II }}$ André Dias de Azevedo Neto ${ }^{\text {III }}$ \\ Angélica Maria Lucchese ${ }^{\mathrm{IV}}$ Lenaldo Muniz de Oliveira $^{\mathrm{V}}$
}

\section{ABSTRACT}

Martianthus leucocephalus is found in the semi-arid Northeast of Brazil and has high pharmacological potential due to the production of volatile compounds. This study aimed to evaluate the

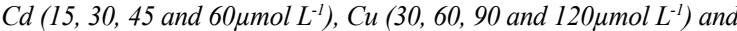
$\mathrm{Zn}\left(150,300,450\right.$ and $\left.600 \mu \mathrm{mol} \mathrm{L}^{-1}\right)$ levels on the growth of this species and its volatile compounds production. Apical cuttings were placed in plastic trays containing 6.0L nutrient solution, and after rooting, they were submitted to $\mathrm{Cd}$, Cu and $\mathrm{Zn}$ treatments for 15 days. All the metals evaluated reduced the succulence and growth of all parts of $\boldsymbol{M}$. leucocephalus. This effect was accompanied by the increase of $\mathrm{Cd}, \mathrm{Cu}$ and $\mathrm{Zn}$ concentrations in all plant tissues. Volatile compounds content produced by M. leucocephalus was increased only by Zn (86\%).

Key words: Lamiaceae, metals, relative growth.

\section{RESUMO}

\begin{abstract}
Martianthus leucocephalus é encontrada no semiárido nordestino e possui potencial farmacológico atribuído à produção de compostos voláteis. Este trabalho objetivou avaliar o efeito de doses de $C d\left(15,30,45\right.$ and $\left.60 \mu \mathrm{mol} \mathrm{L} \mathrm{L}^{-1}\right), C u(30,60,90$ and

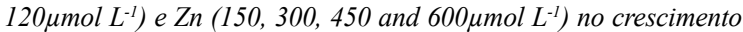
dessa espécie e na produção de compostos voláteis. Estacas apicais foram transferidas para bandejas plásticas contendo 6,0L de solução nutritiva e, após o enraizamento, foram submetidas aos tratamentos de $\mathrm{Cd}$, $\mathrm{Cu}$ e $\mathrm{Zn}$, durante 15 dias. Todos os metais avaliados reduziram a suculência e o crescimento de todas as partes de M. leucocephalus. Este efeito foi acompanhado pelo incremento das concentrações de $\mathrm{Cd}$, Cu e $\mathrm{Zn}$ em todos os tecidos das plantas. Também foi observado que o teor de compostos voláteis, produzido por M. leucocephalus, foi aumentado apenas pelo Zn (86\%).
\end{abstract}

Palavras-chave: Lamiaceae, metais, crescimento relativo.

\section{INTRODUCTION}

Family Lamiaceae is widely used in different parts of the world, both as a medicinal plant and in cooking. Several species, such as rosemary (Rosmarinus sp.), basil (Ocimum sp.) and mint (Mentha sp.) are well established in a number of regions (MARIUTTI \& BRAGAGNOLO, 2007). In this family, the genus Hyptis is highly relevant due to its ability to produce a wide range of pharmacologically significant organic compounds (FALCÃO \& MENEZES, 2003).

Formerly known as Hyptis leucocephala Mart. ex Benth, the M. leucocephalus species is restricted to semi-arid regions and exhibits high phytochemical and economic potential, attributed to the presence of volatile compounds, commonly known as essential oils (OLIVEIRA et al., 2011). According to Lucchese et al. (2006), the essential oil yield of the leaves is nearly $0.2 \%$, which has antimicrobial activity against Bacillus cereus, Stafilococcus aureus and Candida albicans.

Despite its significant potential, few studies investigate the domestication and cultivation of M. leucocephalus, which would facilitate its sustainable economic use. Additional aspects should also be considered for the development of cultivation systems, including factors that can stimulate an

\footnotetext{
IPrograma de Pós-graduação em Recursos Genéticos Vegetais (PPGRGV), Universidade Estadual de Feira de Santana (UEFS), 44036-900, Feira de Santana, BA, Brasil. E-mail: dasilva_jesus@yahoo.com.br. *Corresponding author.

IIInstituto de Química, Universidade Federal da Bahia (UFBA), Salvador, BA, Brasil.

IIICentro de Ciências Exatas e Tecnológicas, Universidade Federal do Recôncavo da Bahia (UFRB), Cruz das Almas, BA, Brasil.

IV Departamento de Ciências Exatas, Universidade Estadual de Feira de Santana (UEFS), Feira de Santana, BA, Brasil.

${ }^{\mathrm{v}}$ Departamento de Ciências Biológicas, Universidade Estadual de Feira de Santana (UEFS), Feira de Santana, BA, Brasil. Received 04.21.15 Approved 07.08.16 Returned by the author 09.23.16 CR-2015-0576.R2
} 
increase in volatile compounds in leaves. In this respect, plant exposure to abiotic stress factors has been shown to modify secondary metabolic pathways (SELMAR \& KLEINWÄCHTER, 2013), increasing the synthesis rate of some products.

One of the abiotic factors that act on secondary metabolism is the accumulation of metals in plants. According to MITHÖFER et al. (2004), a number of species synthesize and accumulate secondary metabolites after treatment with metals. Rosmarinus officinalis L. plants exposed to $\mathrm{Cu}$ exhibited an increase in essential oil content (DEEF, 2007). This trend was also observed in Matricaria chamomilla L. plants (GREJTOVSKY et al., 2006). Additionally, Salvia miltiorrhiza Bunge plants grown in soils containing high levels of $\mathrm{Cd}$ showed accumulation of lipid and water soluble bioactive compounds (LI et al., 2013). Although further research is needed to fully elucidate the effects of metal stress (NASIM \& DHIR, 2010), some results indicated that these substances may be useful as elicitors in plants with a unique metabolism.

Conversely, exposure to high levels of metals also affects plant growth and development, both in the roots and aerial parts (NAGAJYOTI et al., 2010). The same authors also suggested that damage is associated with reduced photosynthetic capacity and excessive production of reactive oxygen species. Although excess metals are typically harmful to plants, the extent of damage may vary, depending on stress intensity, type of metal and plant species (NAGAJYOTI et al., 2010). This study aimed to determine the effect of $\mathrm{Cd}, \mathrm{Cu}$ and $\mathrm{Zn}$ on the growth and volatile compound production of $\boldsymbol{M}$. leucocephalus.

\section{MATERIALS AND METHODS}

Growth conditions and treatments Apical cuttings of M. leucocephalus around $15 \mathrm{~cm}$ long were obtained from the collection of medicinal and herbal plants in the tree nursery of Universidade Estadual de Feira de Santana, Bahia, Brazil. Then, the cuttings were immediately transferred to plastic trays containing six liters of HOAGLAND \& ARNON's (1950) nutrient solution and placed in a greenhouse. The $\mathrm{pH}$ of the solution was adjusted to $6.0 \pm 0.2$ and monitored daily. After ten days, plants were placed in hydroponic system and treatments were applied as follows: control $\left(0.0 \mu \mathrm{mol} \mathrm{L}^{-1}\right.$ metal), $\mathrm{Cd}\left(\mathrm{NO}_{3}\right)_{2}(15,30,45$ and $60 \mu \mathrm{mol} \mathrm{L}-1), \mathrm{CuSO}_{4}(30,60$, 90 and $120 \mu \mathrm{mol} \mathrm{L}-1)$ and $\mathrm{ZnSO}_{4}(150,300,450$ and $\left.600 \mu \mathrm{mol} \mathrm{L}^{-1}\right)$. Metal concentrations were defined as a function of toxicity levels, established by preliminary experiments and results reported in the literature for other species (ZHAO et al., 2010; VASSILEV et al., 2011; AMIRMORADI et al., 2012). Nutrient solutions were replaced once a week and the volume topped up daily. The system was maintained under intermittent aeration (15 minutes every three hours) using an air compressor coupled to a timer. The plants remained under these conditions for 15 days.

\section{Growth analysis}

Plants were collected one day before and 15 days after the application of treatments and weighed by using an analytical balance to determine the fresh weight of the leaves (LFW), stem (SFW) and roots (RFW). Next, the plant matter was placed in paper bags and transferred to a forced air oven $\left(60^{\circ} \mathrm{C}\right)$ until constant weight in order to determine total dry weight (TDW) as well as that of leaves (LDW), stem (SDW), and roots (RDW). Based on these data, it was calculated the relative growth rate (RGR) and the succulence (Suc) in accordance with the methodology proposed by EL-LITHY et al. (2004), using the following equations:

$\operatorname{RGR}\left(\mathrm{g} \mathrm{g}^{-1} \mathrm{~d}^{-1}\right)=\left(\mathrm{nl} \mathrm{TDW}_{2}-\mathrm{nl} \mathrm{TDW}_{1}\right) /\left(\mathrm{t}_{2}-\mathrm{t}_{1}\right)^{-1}$ $\mathrm{SUC}\left(\mathrm{g} \mathrm{H}_{2} \mathrm{O} \mathrm{g}^{-1} \mathrm{DW}\right)=\left(\mathrm{LFW}_{2}-\mathrm{LDW}_{2}\right) / \mathrm{LDW}_{2}$ where: $\mathrm{LFW}_{2}$ : final fresh weight of the leaves; $\mathrm{LDW}_{2}$ : final dry weight of the leaves; nl: Napierian logarithm; $\mathrm{TDW}_{1}$ : initial total dry weight; $\mathrm{TWD}_{2}$ : final total dry weight and $\left(\mathrm{t}_{2}-\mathrm{t}_{1}\right)$ time interval $(15 \mathrm{~d})$.

The experimental design was a completely randomized, with four replications per treatment. Results were submitted to variance analysis by F-test. When observed significance, the data were subjected to regression analysis using SISVAR statistical software (FERREIRA, 2003).

\section{Volatile compounds analysis}

Volatile compounds were extracted using a Clevenger distillation apparatus. For each sample, 1.5 to $3 \mathrm{~g}$ LDW of M. leucocephalus was used. Distillation time was $3 \mathrm{~h}$. The volatile compounds and water were collected in a separatory funnel. We added $10 \mathrm{~mL}$ dichloromethane three times in succession, followed by magnesium sulfate to separate residual water. Mixture was placed into a rotary evaporator to remove the dichloromethane. Volatile compound content was quantified by gravimetry on analytical balance and expressed in mg per 100g LDW, and mg per plant (leaves).

\section{Metal concentration analysis}

The extracts were obtained by acid digestion in concentrated $\mathrm{HNO}_{3}$ and $\mathrm{H}_{2} \mathrm{O}_{2}(30 \%)$ using 
a digestion block at $125^{\circ} \mathrm{C}$ for $60 \mathrm{~min}$, as described by JONES (2001). Digested material was adjusted to $50 \mathrm{~mL}$ with deionized water. Cadmium, copper and zinc were measured by inductively coupled plasma optical emission spectroscopy (Simultaneous Varian VISTA-PRO ICP-OES).

\section{RESULTS}

Figures 1 and 2 illustrate that increased $\mathrm{Cd}, \mathrm{Cu}$ and $\mathrm{Zn}$ concentrations in the nutrient solution reduced all the growth variable, whereas, $\mathrm{Zn}$ addition raised the volatile compound content (Figure 3).

Comparison of effects of metal treatments on each part of plants showed greater damage in the leaves, where $\mathrm{Cd}, \mathrm{Cu}$ and $\mathrm{Zn}$ caused average reductions of 70,81 and $85 \%$, respectively (Figure 1). The part least effected by $\mathrm{Cd}$ was the root, with a $56 \%$ reduction at the highest tested dose of this metal compared to the 70 and $73 \%$ decreases recorded in LDW and SDW, respectively. However, in plants submitted to higher levels of $\mathrm{Cu}$ and $\mathrm{Zn}$, the least effected region was the stem (63 and 75\%). With respect to TDW, plants exposed to the highest doses of $\mathrm{Cd}$ and $\mathrm{Cu}$ exhibited around $75 \%$ decline in relation to controls (Figure 1). In plants submitted to the highest $\mathrm{Zn}$ level, the decline was greater (approximately 85\%).

Results showed that increased levels of $\mathrm{Cd}, \mathrm{Cu}$ and $\mathrm{Zn}$ in the nutrient solution increased the accumulation of these elements in all parts of $\boldsymbol{M}$. leucocephalus (Figure 2). Regardless of the metal and dose applied, concentrations were always higher in roots than in other parts of plants (Figure 2). In plants submitted to $\mathrm{Cu}$ and $\mathrm{Zn}$ stress, levels of these metals were similar in stems and leaves. However, for plants exposed to $\mathrm{Cd}$ stress, concentrations of this metal were five times higher in stems than in the leaves.

Relative growth rate (RGR) values of plants exposed to the highest $\mathrm{Cd}, \mathrm{Cu}$ and $\mathrm{Zn}$ levels displayed reductions of 59,78 and $86 \%$, respectively, in relation to controls (Figure 3). Succulence of leaves submitted to the largest doses of $\mathrm{Cd}, \mathrm{Cu}$ and $\mathrm{Zn}$ fell by approximately half the amount observed in non-stressed plants (Figure 3). Among the metals tested, $\mathrm{Zn}$ induced an increased in volatile compound concentration of M. leucocephalus, at all doses. Treatment with $450 \mu \mathrm{M}$ of this metal produced an average of $0.31 \mathrm{mg} \mathrm{g}^{-1}$ leaf, equivalent to $86 \%$ increase in relation to the value reported in control plants (Figure 3). Treatment of $60 \mu \mathrm{mol} \mathrm{L} \mathrm{L}^{-1}$ of $\mathrm{Cu}$ also increased the volatile compounds yield in $42 \%$. Conversely, all metals caused a decrease in the production of volatile compounds of $\boldsymbol{M}$. leucocephalus. Thus, in the higher doses of $\mathrm{Cd}, \mathrm{Cu}$ and $\mathrm{Zn}$, these reductions reached 68,77 and $75 \%$ (Figure 3).

\section{DISCUSSION}

Assessing plant performance based on growth made possible to determine the toxicity of the elements applied in M. leucocephalus. Thus, $\mathrm{Cu}$ and Cd caused similar declines in TDW despite the fact that double the amount of $\mathrm{Cu}$ was applied, suggesting that $\mathrm{Cd}$ is more toxic in this species. Conversely, although effects of Zn stress on TDW were relatively more severe, concentration used was 10 and 5 times higher than that of $\mathrm{Cd}$ and $\mathrm{Cu}$, respectively. Thus, results indicated increasing phytotoxicity of $\mathrm{Cd}>\mathrm{Cu}>\mathrm{Zn}$ on growth of $M$. leucocephalus.

Regardless of the metal applied, LDW was always more affected by stress than the other plant parts and levels of toxic metals in the leaves were always lower than those in the stem and roots. Thus, the data suggested that M. leucocephalus leaves are more sensitive to the accumulation of metals than other parts of the plant.

Roots accumulated more metals than leaves and stems, indicating low translocation from the root to the aerial part of the plant (ALI et al., 2012). In addition, the results confirmed that $\mathrm{Cu}$ and $\mathrm{Zn}$ are deemed to have low mobility in plants (MARSCHNER, 2012). Conversely, the internal transport rate of $\mathrm{Cd}$ varies considerably among species (CHOPRA \& PATHAK, 2012). As such, results of this study demonstrated low mobility of this metal in M. leucocephalus. Additionally, the limited translocation of toxic elements from roots to aerial parts is also considered significant in plant tolerance to metal stress (YANG et al., 2003).

As with TDW, there was a decline in the relative growth rate (RGR) with the increased concentrations of all metals tested. This rate represents the periodic increase in plant DW in relation to the preexisting DW (EL-LITHY et al., 2004). Considering the more pronounced decrease in DW caused by the toxicity of these metals in leaves, data suggested that toxicity of metals tested can reduce photosynthetic capacity of M. leucocephalus. Photosynthetic disorders are often observed in plants exposed to high metal levels (NAGAJYOTI et al., 2010).

Metal stress has been reported as a factor that causes water stress in plants (PÁL et al., 2006), an effect also observed in M. leucocephalus and evident in its decreased succulence (Suc). When 


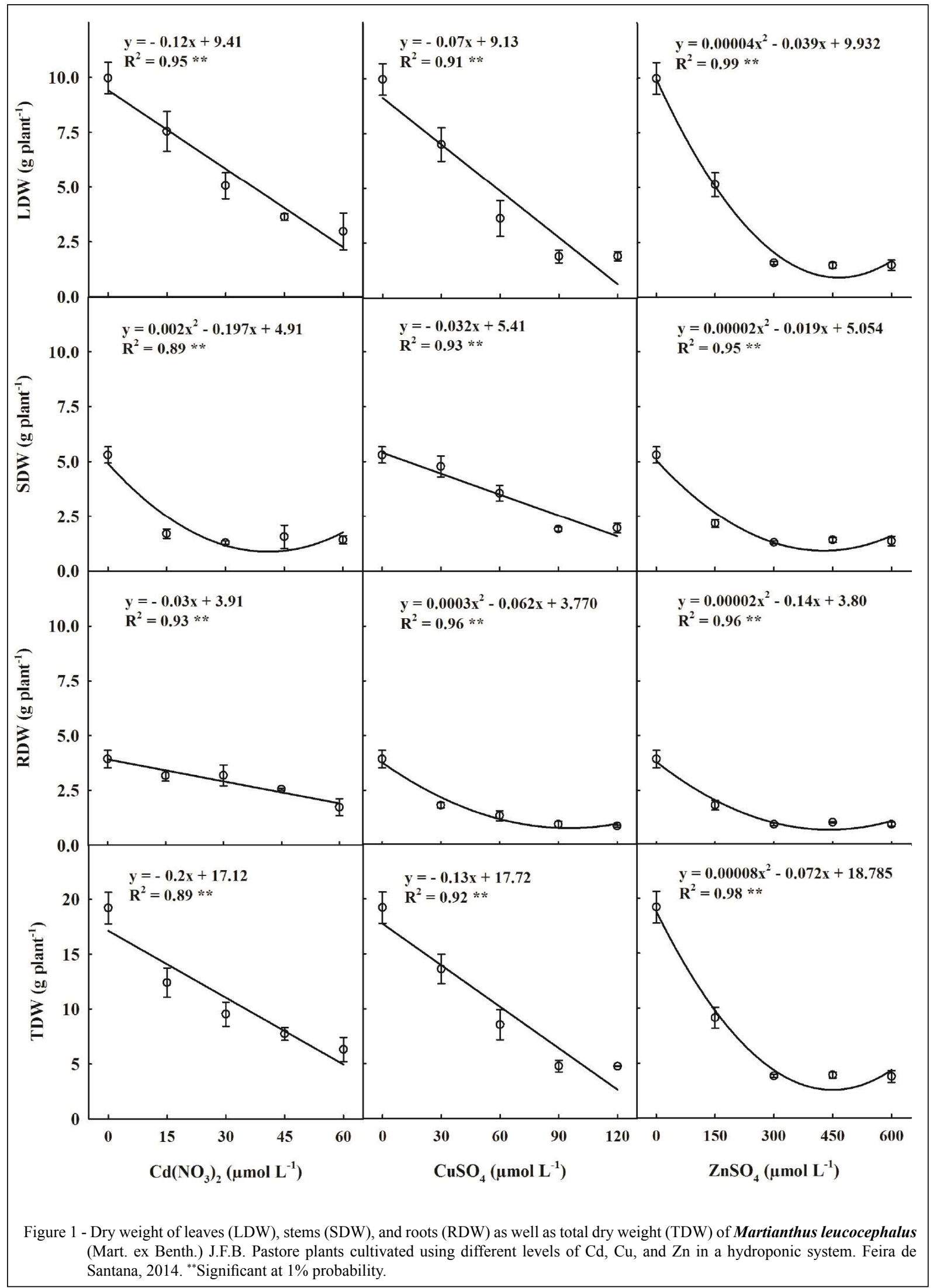

Ciência Rural, v.46, n.12, dez, 2016. 


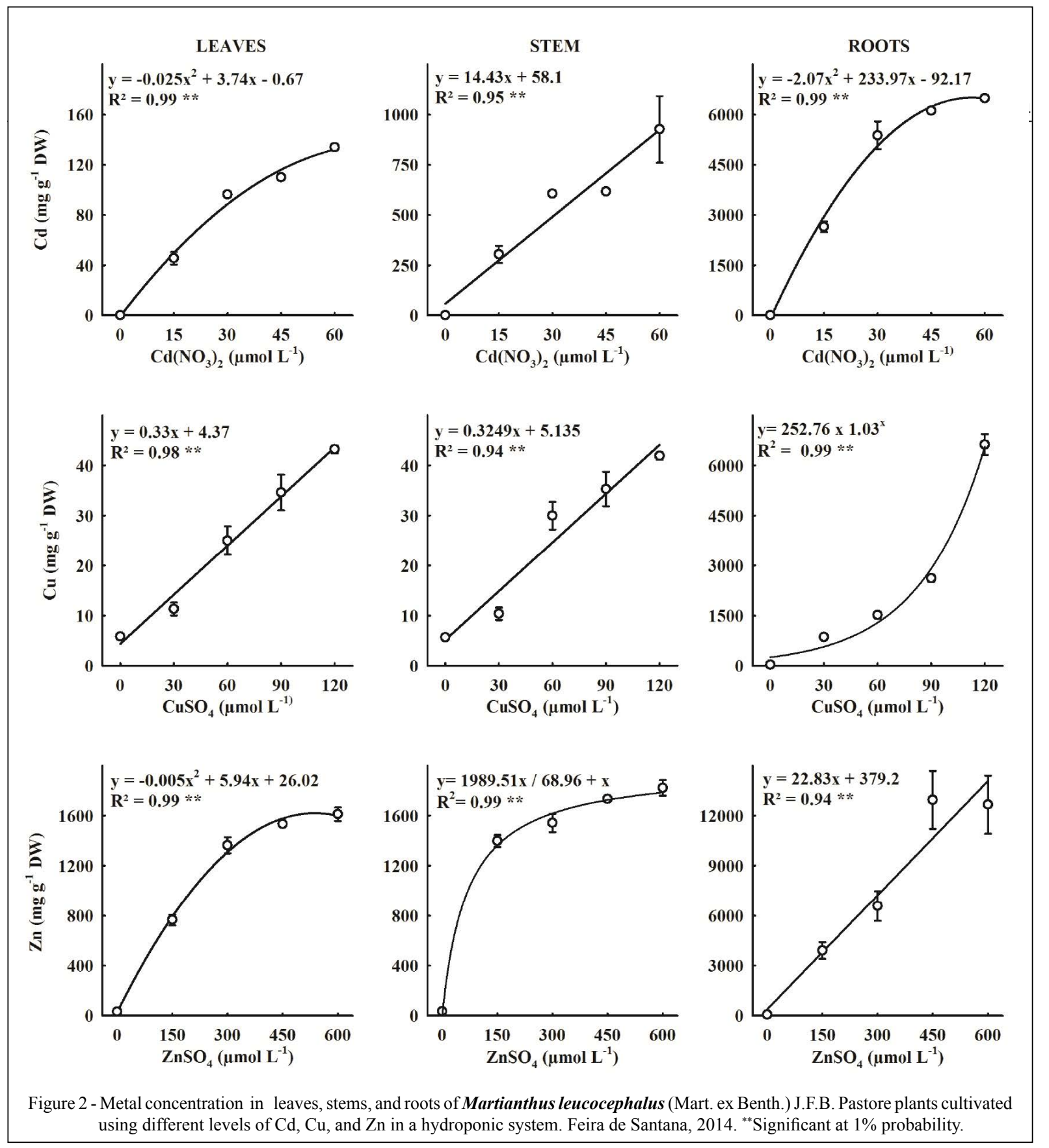

plants were exposed to higher levels of $\mathrm{Cd}, \mathrm{Cu}$ and $\mathrm{Zn}$, succulence fell by around half the values obtained in controls. Compromised water balance in plants exposed to heavy metals has been linked to reductions in membrane permeability and vascular bundle diameter, in addition to inhibiting formation of root hairs (PÁL et al., 2006). Water is an essential component in promoting growth and cell division (JALEEL et al., 2009). Thus, results obtained in this study suggested that reduced succulence in M. leucocephalus tissue submitted to treatment with $\mathrm{Cd}, \mathrm{Cu}$ and $\mathrm{Zn}$ partially explains growth decline in this species.
Results illustrated that volatile compound content increased with $\mathrm{Zn}$ exposure (Figure 3). This increase in volatile compounds in plants exposed to $\mathrm{Zn}$ suggested a concentration effect, given the reduction in leaf growth. The observation that the volatile compounds production was lower in metals treated plants supports this hypothesis. Alternatively, Zn-induced stress may have increased activity of enzymes isopentenyl pyrophosphate: dimethylallyl pyrophosphate isomerase and phenylalanine ammonia lyase (LUCINI \& BERNARDO, 2015). These are key enzymes in the terpenes and phenylpropanoids biosynthesis, the main components of plant essential 


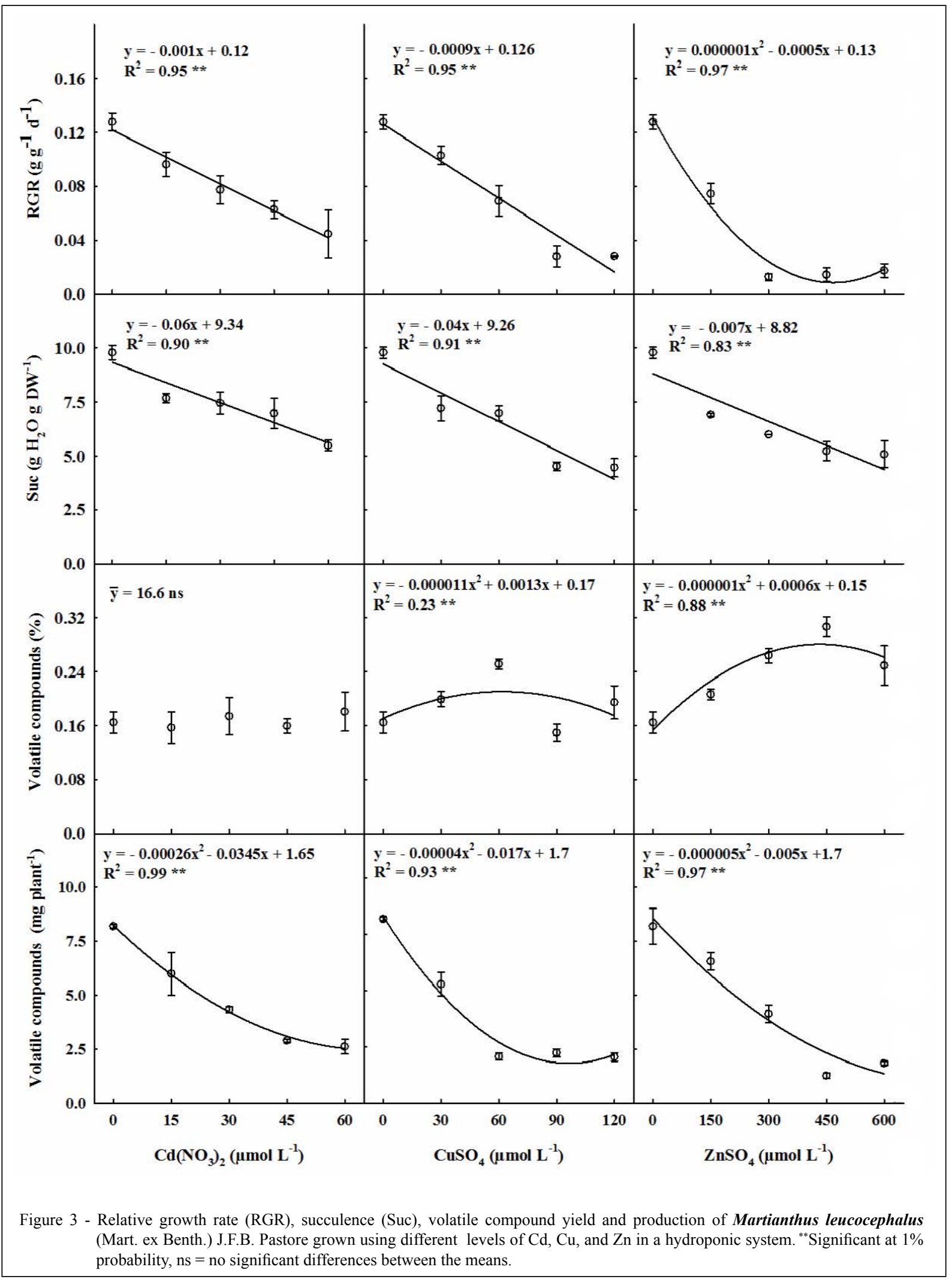

Ciência Rural, v.46, n.12, dez, 2016. 
oils (MIGUEL, 2010). As the reduction in dry matter yield can be compensated by a higher plant density, M. leucocephalus cultivation with reduced spacing between plants may result in a real increase in volatile compound yield in $\mathrm{Zn}$-contaminated soil.

Production of volatile compounds in plants may be an important mechanism in minimizing damage caused by abiotic stress (TURTOLA et al., 2003). A number of these substances can protect plant species from oxidative stress in adverse environmental conditions, such as high heavy metal levels (SELMAR \& KLEINWÄCHTER, 2013). According to these authors, plants can maintain volatile compound production even under very negative conditions and with photosynthesis severely compromised. Accordingly, results of this study showed that growth was more affected by the presence of metals than volatile compound content, suggesting that these compounds play an important role in the metabolism of M. leucocephalus, even in adverse conditions.

\section{CONCLUSION}

The $\mathrm{Cd}, \mathrm{Cu}$ and $\mathrm{Zn}$ stresses reduced growth of M. leucocephalus; however, volatile compounds concentration increase in the $\mathrm{Zn}$ presence. Considering that the growth reduction may be compensated by the increase in plant density, new researches should be performed in $\mathrm{Zn}$ contaminated soils, evaluating the effect of plant density in volatile compounds production of M. leucocephalus.

\section{ACKNOWLEDGEMENTS}

The authors are grateful to the Coordenação de Aperfeiçoamento de Pessoal de Nível Superior (CAPES) and the Fundação de Amparo à Pesquisa do Estado da Bahia (FAPESB) for financial support.

\section{REFERENCES}

ALI, H. et al. Phytoremediation of heavy metals by Trifolium alexandrinum. International Journal of Environmental Sciences, v.2, p.1459-1469, 2012. Available from: <http://www. ipublishing.co.in/ijesarticles/twelve/articles/voltwo/EIJES3136. pdf $>$. Accessed: Mar. 15, 2015. doi: 10.6088/ijes.00202030031.

AMIRMORADI, S. et al. Effect of cadmium and lead on quantitative and essential oil traits of peppermint (Mentha piperita L.). Notulae Scientia Biologicae, v.4, p.101-109, 2012. Available from: <http://notulaebiologicae.ro/index.php/nsb/article/ view/8185>. Accessed: Nov. 10, 2013.

CHOPRA, A.K.; PATHAK, C. Bioaccumulation and translocation efficiency of heavy metals in vegetables grown on long-term wastewater irrigated soil near bindal river, dehradun. Agricultural
Research, v.1, p.157-164, 2012. Available from: <http://link. springer.com/article/10.1007/s40003-012-0016-8>. Accessed: Mar. 15, 2015. doi: 10.1007/s40003-012-0016-8.

DEEF, H.E. Cupper treatments and their effects on growth, carbohydrates, minerals and essential oils contents of Rosmarinus officinalis L. World Journal of Agricultural Sciences, v.3, n.3, p.322-328, 2007. Available from: < http://www.idosi.org/wjas/ wjas3(3)/10.pdf $>$. Accessed: Jan. 12, 2011.

EL-LITHY, M.E. et al. Quantitative trait locus analysis of growthrelated traits in a new Arabidopsis recombinant inbred population. Plant Physiology. v.135, n.01, p.444-458, 2004. Available from: <http://www.ncbi.nlm.nih.gov/pmc/articles/PMC429397/>. Accessed: Aug. 09, 2016. doi: 10.1104/pp.103.036822.

FALCÃO, D.Q.; MENEZES, F.S. The Hyptis genus: an ethnopharmacological and chemical review. Revista Brasileira de Farmácia, v.84, p.68-74, 2003. Available from: <http://rbfarma. org.br/files/pag_69a74_vjml00dk.pdf>. Accessed: Jan. 12, 2011.

FERREIRA, D.F. SISVAR 4.6 sistema de análises estatísticas. Lavras: UFLA, 2003. 32p.

GREJTOVSKY, A. et al. The response of chamomile (Matricaria chamomilla L.) plants to soil zinc supply. Plant Soil Environmental, v.52, p.1-7, 2006. Available from: <http://www.agriculturejournals. cz/publicFiles/50510.pdf>. Accessed: Oct. 20, 2012.

HOAGLAND, D.R.; ARNON, D.I. The water culture method for growing plants without soil. California Agricultural Experiment Station Circular, v.347, p.1-32, 1950.

JALEEL, C.A. et al. Drought stress in plants: a review on morphological characteristics and pigments composition. International Journal of Agriculture and Biology, v.11, p.100-105, 2009. Available from: <http://www.fspublishers.org/ published_papers/84178_..pdf>. Accessed: Feb. 13, 2014.

JONES, J.B. Jr. Laboratory guide for conducting soil tests and plant analysis. Boca Raton: CRC, 2001. 363p.

LI, X. et al. Effect of cadmium in the soil on growth, secondary metabolites and metal uptake in Salvia miltiorrhiza. Toxicological \& Environmental Chemistry, v.95, n.9, p.1525-1538, 2013. Available from: $<$ http://dx.doi.org/10.1080/02772248.2014.88771 7>. Accessed: Oct. 28, 2014. doi: 10.1080/02772248.2014.887717.

LUCCHESE, A.M. et al. Comparação da atividade antimicrobiana de óleos essenciais extraídos de espécies do semi-árido baiano. In: REUNIÃO ANUAL DA SOCIEDADE BRASILEIRA DE QUÍMICA, 29., 2006, Águas de Lindóia. Anais... Águas de Lindóia: Sociedade Brasileira de Química, 2006. p.285.

LUCINI, L.; BERNARDO, L. Comparison of proteome response to saline and zinc stress in lettuce. Frontiers in Plant Science, v.6, n.240, 2015. Available from: <http://journal.frontiersin.org/ article/10.3389/fpls.2015.00240/abstract $>$. Accessed: Aug. 06, 2015. doi: $10.3389 /$ fpls.2015.00240.

MARSCHNER, P. Marschner's mineral nutrition of higher plants. 3.ed. Londres: Academic, 2012. 651p.

MARIUTTI, L.R.B.; BRAGAGNOLO, N. Review: Natural Antioxidants from the Lamiaceae Family. Application in Food Products. Brazilian Journal of Food, v.10, p.96-103, 2007. 
Available from: <http://bj.ital.sp.gov.br/artigos/html/busca/PDF/ v10n2278p.pdf>. Accessed: Mar. 31, 2013.

MITHÖFER, A. et al. Biotic and heavy metal stress response in plants: evidence for common signals. FEBS Letters, v.566, p.1-5, 2004. Available from: <http://onlinelibrary.wiley.com/ doi/10.1016/j.febslet.2004.04.011/epdf $>$. Accessed: Dec. 13, 2013. doi: 10.1016/j.febslet.2004.04.011.

MIGUEL, M.G. Antioxidant and anti-inflammatory activities of essential oil: a short revision. Molecules, v.15, p.9252-9287, 2010 Available from: <http://www.mdpi.com/1420-3049/15/12/9252> Accessed: Dec. 13, 2013. doi: 10.3390/molecules 15129252.

NAGAJYOTI, P.C. et al. Heavy metals, occurrence and toxicity for plants: a review. Environmental Chemistry Letters, v.8, p.199216, 2010. Available from: $<$ http://link.springer.com/article/10.100 7\%2Fs10311-010-0297-8>. Accessed: Jan. 12, 2011. doi: 10.1007/ s10311-010-0297-8

NASIM, S.A.; DHIR, B. Heavy metal alter the potency of medicinal plants. Reviews of Environmental Contamination and Toxicology, v.203, p.139-149, 2010. Available from: <http:// link.springer.com/chapter/10.1007\%2F978-1-4419-1352-4 5>. Accessed: Oct. 28, 2012. doi: 10.1007/978-1-4419-1352-4_5.

OLIVEIRA, L.M. et al. Vegetative propagation of Hyptis leucocephala Mart. ex Benth. and Hyptis platanifolia Mart. ex Benth Revista Brasileira de Plantas Medicinais, v.13, p.73-78, 2011. Available from: $<$ http://www.scielo.br/scielo.php?script=sci_arttext\& pid=S1516-05722011000100011>. Accessed: Dec. 13, 2013.

PÁL, M. et al. Physiological changes and defense mechanisms induced by cadmium stress in maize. Journal of Plant Nutrition and Soil Science, v.169, p.239-246, 2006. Available from: <http:// onlinelibrary.wiley.com/doi/10.1002/jpln.200520573/abstract $>$. Accessed: Jan. 07, 2014. doi: 10.1002/jpln.200520573.

SELMAR, D.; KLEINWÄCHTER, M. Stress enhances the synthesis of secondary plant products: the impact of stress-related over-reduction on the accumulation of natural products. Plant and Cell Physiology, v.54, p.817-826, 2013. Available from: <http:// pcp.oxfordjournals.org/content/54/6/817.long>. Accessed: Jan. 07, 2014. doi: $10.1093 / \mathrm{pcp} / \mathrm{pct} 054$

TURTOLA, S. et al. Drought stress alters the concentration of wood terpenoids in Scots pine and Norway spruce seedlings. Journal of Chemical Ecology, v.29, p.1981-1995, 2003. Available from: $<$ http://link.springer.com/article/10.1023\%2FA\% 3A1025674116183>. Accessed: Oct. 28, 2012.

VASSILEV, A. et al. Effects of excess $\mathrm{Zn}$ on growth and photosynthetic performance of young bean plants. Journal of Phytology, v.3, p.5862, 2011. Available from: <http://scienceflora.org/journals/index.php/ jp/article/viewFile/2279/2257>. Accessed: Feb. 12, 2013.

YANG, B. et al. Growth and metal accumulation in vetiver and two Sesbania species on lead/zinc mine tailings. Chemosphere, v.52, p.1593-1600, 2003. Available from: <http://www.sciencedirect. com/science/article/pii/S0045653503004995>. Accessed: Oct. 12, 2013. doi: 10.1016/S0045-6535(03)00499-5.

ZHAO, S. et al. Responses of root growth and protective enzymes to copper stress in turfgrass. Acta Biologica Cracoviensia Series Botanica, v.52, p.7-11, 2010. Available from: <http://www. degruyter.com/view/j/abcsb.2010.52.issue-2/v10182-010-0017-5/ v10182-010-0017-5.xml>. Accessed: Jan. 07, 2014. doi: 10.2478/ v10182-010-0017-5 